ELAINE CYRENO OLIVEIRA

\title{
ADESÃO E ATIVIDADE DE PROTEASE SÃO REGULADAS PELO PEPTÍDEO DERIVADO DA LAMININA AG73, SINDECAN-1 E INTEGRINA $\beta 1$ EM LINHAGEM CELULAR DERIVADA DE CARCINOMA ADENÓIDE CÍSTICO
}

Tese apresentada ao Programa de PósGraduação em Biologia Celular e Tecidual do Instituto de Ciências Biomédicas da Universidade de São Paulo, para obtenção do Título de Doutor em Ciências Biológicas.

São Paulo

2009 


\section{RESUMO}

CYRENO-OLIVEIRA, E. Adesão e atividade de protease são reguladas pelo peptídeo derivado da laminina AG73, sindecan-1 e integrina $\beta 1$ em linhagem celular derivada de carcinoma adenóide cístico. 2009. $131 \mathrm{f}$. Tese (Doutorado em Biologia Celular e Tecidual) - Instituto de Ciências Biomédicas, Universidade de São Paulo, São Paulo, 2009.

Estudamos indução da atividade de protease pelo peptídeo derivado da laminina a1 AG73 em linhagem celular (CAC2) de carcinoma adenóide cístico. Cadeia $\alpha 1$ da laminina e MMP9 foram imunolocalizadas em carcinoma adenóide cístico in vivo e in vitro. Células crescidas em laminina-111 enriquecida por AG73 exibiram espaços na matriz extracelular, sugestivos de remodelação. Inibidor de MMP diminuiu tais espaços, sugerindo que a remodelação envolve MMPs. CAC2 crescidas sobre AG73 mostraram aumento dose-dependente da secreção de MMP9. Silenciamento de MMP9 por RNAi diminuiu remodelação em cultura 3D. Buscamos receptores de AG73 relacionados à atividade de MMP9. CAC2 crescidas sobre AG73 exibiram colocalização de sindecan-1 e integrina $\beta 1$. Silenciamento de sindecan-1 resultou em decréscimo da adesão a AG73 e redução nas atividades de remodelação e de protease. Investigamos coreceptores de sindecan-1 nas células CAC2. RNAi para integrina $\beta 1$ inibiu adesão a AG73, remodelação da matriz e atividade de MMP. Duplo RNAi foi feito para explorar cooperação entre esses receptores. CAC2 transfectadas com ambos RNAis mostraram diminuição na adesão a AG73. Silenciamento simultâneo também induziu diminuição da atividade de MMP. Caracterização dos receptores foi feita por cromatografia de afinidade seguida de espectrometria de massa. Preparações de membranas passaram através de colunas de afinidade com AG73 acoplado. Bandas eluídas e analisadas mostraram possíveis receptores, entre eles integrinas $\beta 1 \mathrm{e} \alpha \mathrm{V}$. Sugerimos que AG73 regula adesão e produção de MMP em células de carcinoma adenóide cístico através de sindecan-1 e integrina $\beta 1$.

Palavras-Chave: Carcinoma Adenóide Cístico. Matriz Extracelular. Laminina. Sindecan. Integrinas. Metaloproteinases da Matriz. 
ABSTRACT

CYRENO-OLIVEIRA, E. Ahesion and protease activity are regulated by the laminin-derived peptide AG73, syndecan-1 and $\beta 1$ integrin in cell line derived from adenoid cystic carcinoma. 2009. $131 \mathrm{f}$. Ph. D. Thesis (Tecidual and Cellular Biology) - Instituto de Ciências Biomédicas, Universidade de São Paulo, São Paulo, 2009.

We studied induction of protease activity by $\alpha 1$ laminin-derived peptide AG73 in a cell line (CAC2) from adenoid cystic carcinoma. Laminin $\alpha 1$ chain and MMP9 were immunolocalized in adenoid cystic carcinoma in vivo and in vitro. Cells grown inside AG73-enriched laminin-111 exhibited spaces in the extracellular matrix, suggestive of remodeling. MMP inhibitor decreased those spaces, suggesting that AG73-mediated matrix remodeling involves matrix metalloproteinases. CAC2 cells grown on AG73 showed a dose-dependent increase of MMP9 secretion. siRNA silencing of MMP9 decreased remodeling in 3D culture. We searched for AG73 receptors regulating MMP9 activity in CAC2 cells. CAC2 grown on AG73 exhibited colocalization of syndecan- 1 and $\beta 1$ integrin. siRNA silencing of syndecan-1 resulted in decreased adhesion to AG73 and reduced protease and remodeling activity. We investigated syndecan-1 coreceptors in CAC2 cells. siRNA silencing of $\beta 1$ integrin inhibited adhesion to AG73, matrix remodeling and MMP activity. Double-knockdown were carried out to explore syndecan-1 and $\beta 1$ integrin cooperation. CAC2 cells CAC2 transfected with both siRNA showed decrease in adhesion to AG73. Simultaneous silencing also induced a decrease in MMP activity. We further characterized receptors by affinity chromatography followed by mass spectrometry. Membrane preparations from CAC2 cells were run through AG73-affinity columns. Eluted bands were analyzed by mass spectrometry and showed putative receptors, like $\beta 1$ and $\alpha \mathrm{V}$ integrins, confirming our results. We suggest that AG73 peptide regulates adhesion and MMP secretion in cells from adenoid cystic carcinoma through syndecan-1 and $\beta 1$ integrin.

Keywords: Adenoid Cystic Carcinoma. Extracellular Matrix. Laminin. Syndecan. Integrins. Matrix Metalloproteinases. 


\section{INTRODUÇÃO}

O carcinoma adenóide cístico é frequente neoplasia maligna de glândula salivar com recorrência e metástase mesmo após tratamento (SEIFERT e SOBIN, 1992). Exibe diferentes subtipos histológicos, podendo ser sólido, tubular ou pseudocístico (DARDICK, 1996; SEIFERT e SOBIN, 1992). Característica importante do carcinoma adenóide cístico é a sua afinidade por tecidos ricos em membrana basal, o que facilita a disseminação peri-vascular ou peri-neural (SEIFERT e SOBIN, 1992). Adicionalmente, essa neoplasia expressa uma matriz extracelular proeminente (CHENG et al., 1995; CHENG et al., 1992). A matriz extracelular desempenha importante papel como fator regulador das diferenças fenotípicas nas neoplasias de glândula salivar (CAPUANO e JAEGER, 2004; DE OLIVEIRA et al., 2001; FRANCA et al., 2000; FRANCA et al., 2001; FREITAS e JAEGER, 2002; FREITAS et al., 2004; JAEGER, M. M. et al., 1997).

A matriz extracelular é composta por uma grande variedade de moléculas estruturais, como colágenos, glicoproteínas não-colágenas e proteoglicanos. Além disso, é uma estrutura ativa e funciona como um reservatório biológico para uma variedade de componentes. Esses, por sua vez, desempenham papel complexo na regulação do comportamento das células com as quais fazem contato, influenciando seu desenvolvimento, crescimento, sobrevivência, migração, transdução de sinais, forma e função (ALBERTS et al., 2004; AUMAILLEY e GAYRAUD, 1998; BORG, 2004; BORNSTEIN e SAGE, 2002; COMOGLIO e TRUSOLINO, 2005; KLEINMAN et al., 2003; MINER e YURCHENCO, 2004; MOTT e WERB, 2004; PIEZ, 1997; PUPA et al., 2002; SCHENK e QUARANTA, 2003; VU, 2001; YURCHENCO e O'REAR, 1994).

A membrana basal é uma especialização da matriz extracelular. Essa importante estrutura é uma fina rede tridimensional de macromoléculas incluindo, colágeno, laminina, nidogênio e proteoglicano de heparan sulfato, que representa não somente um sólido suporte para as células, mas também atua como fonte de citocinas e fatores de crescimento (AUMAILLEY et al., 2005; EKBLOM, 1996; KLEINMAN et al., 2003). 
Vários estudos mostraram que componentes da matriz extracelular e da membrana basal contêm domínios crípticos, que são expostos através de proteólise e estimulam respostas biológicas diferentes daquelas estimuladas pelas moléculas intactas (FAISAL KHAN et al., 2002; MOTT e WERB, 2004; SCHENK e QUARANTA, 2003). Esses domínios expostos por proteólise são chamados de matricriptinas, matricinas, ou sítios crípticos (FAISAL KHAN et al., 2002; MOTT e WERB, 2004; SCHENK e QUARANTA, 2003). Os sítios crípticos são representados por fragmentos e peptídeos bioativos, os quais estão possivelmente presentes na maioria das moléculas da matriz extracelular (DAVIS et al., 2000; MOTT e WERB, 2004; SCHENK e QUARANTA, 2003). Dentre as proteínas da matriz, a laminina possui múltiplos sítios crípticos relacionados com diferentes atividades biológicas, incluindo adesão, migração, diferenciação, angiogênese e secreção de protease (FREITAS e JAEGER, 2002; FREITAS et al., 2004; GRANT et al., 1992; HOFFMAN et al., 1998; MALINDA e KLEINMAN, 1996; NOMIZU et al., 1998).

Nosso laboratório já demonstrou que a laminina-111 (antiga laminina 1, AUMAILLEY et al., 2005) regula o fenótipo de linhagens celulares derivadas de carcinoma adenóide cístico (células CAC2) e de miopitelioma (células M1) (CAPUANO e JAEGER, 2004; FRANCA et al., 2000; FRANCA et al., 2001; FREITAS e JAEGER, 2002; FREITAS et al., 2004; FREITAS et al., 2007; JAEGER et al., 2008; MORAIS FREITAS et al., 2007). Adicionalmente, esses dois tumores dividem a mesma origem: células do ducto intercalado da glândula salivar (BATSAKIS, 1980).

Crescimento de células CAC2 dentro de gel de laminina-111 criou estruturas semelhantes a ductos e pseudocistos, recapitulando o fenótipo da neoplasia in vivo (FREITAS e JAEGER, 2002; FREITAS et al., 2004). Além de estudarmos os efeitos da molécula íntegra de laminina-111, temos atualmente analisado os efeitos de domínios particulares dessa molécula em células CAC2 e M1. Esses estudos começaram com o peptídeo SIKVAV (FREITAS e JAEGER, 2002; FREITAS et al., 2004; FREITAS et al., 2007), derivado da cadeia $\alpha 1$ da laminina-111. Este peptídeo foi capaz de regular a morfologia e também estimular secreção de protease em células CAC2 (FREITAS e JAEGER, 2002; FREITAS et al., 2004; FREITAS et al., 2007). 
Entre os peptídeos bioativos derivados da laminina, a sequência RKLQVQLSIRT (denominada AG73 e localizada no domínio globular LG4 da cadeia $\alpha 1$ ) é um dos mais efetivos em muitos ensaios biológicos (NOMIZU et al., 1995). O peptídeo AG73 tem sido testado in vivo e in vitro em diferentes células e sitemas (ENGBRING et al., 2002, in press; HOFFMAN et al., 2001; HOFFMAN et al., 1998). Promove adesão em vários tipos celulares (NOMIZU et al., 1995, NOMIZU et al., 1998), induz diferenciação de ácinos em linhagem celular derivada de glândula salivar (HOFFMAN et al., 1998), estimula secreção de metaloproteases de matriz pelas células PC12 (WEEKS et al,. 1998), entre outras atividades.

O peptídeo AG73 também possui importante relevância na biologia tumoral (ENGBRING et al., 2002, in press; KIM et al., 1998; MOCHIZUKI et al., 2007; SONG et al., 1997; SUZUKI et al., 2005). Foi capaz de causar metástase no fígado e aumentada colonização pulmonar de células de melanoma (B16F10) (KIM et al., 1998; SONG et al., 1997). Células de câncer de ovário aumentaram a metástase na presença de AG73 (YOSHIDA et al., 2001). Este peptídeo também está relacionado à angiogênese em diferentes sistemas, tais como o brotamento do anel da aorta e a formação do tubo endotelial, entre outros (MOCHIZUKI et al., 2007).

Apesar de toda a sua importância biológica, os mecanismos que regulam a biotividade de AG73 não estão completamente elucidados.

Nesse trabalho estudamos os mecanismos regulatórios envolvidos nos processos de adesão, migração, invasão e de atividade de protease induzidas pelo peptídeo AG73 nas células CAC2, derivadas de carcinoma adenóide cístico humano. Analisamos, também, os receptores celulares relacionados com esses eventos. 


\section{CONCLUSÃO}

Baseados nos resultados dos experimentos realizados, concluímos que:

1) A cadeia $\alpha 1$ da laminina e a MMP9 são expressas in vivo e in vitro no carcinoma adenóide cístico.

2) AG73 induz remodelação da matriz extracelular, atividades de adesão, migração, invasão e secreção de protease em células CAC2.

3) Espectrometria de massa confirmou sindecan-1 e integrina $\beta 1$ como potenciais ligantes do peptídeo AG73.

4) Adicionalmente, outros ligantes de AG73 foram caracterizados, como integrina $\alpha \mathrm{V}$, vinculina e colágeno $\alpha 1$.

5) As atividades de adesão e secreção de MMPs induzidas por AG73 tem participação de receptores como sindecan-1 e integrina $\beta 1$. 


\section{REFERÊNCIAS*}

ALBERTS, B. et al. (Ed.). Biologia Molecular da Célula. 4 ed. Porto Alegre: Artmed, 2004. p. 1463.

ANTTONEN, A. et al. High syndecan-1 expression is associated with favourable outcome in squamous cell lung carcinoma treated with radical surgery. Lung Cancer, v. 32, n. 3, p. 297-305, 2001.

AUMAILLEY, M. Structure and supramolecular organization of basement membranes. Kidney Int. Suppl., v. 49, p. S4-7, 1995.

AUMAILLEY, M. et al. A simplified laminin nomenclature. Matrix Biol., v. 24, n. 5, p. 326-32, 2005.

AUMAILLEY, M.; GAYRAUD, B. Structure and biological activity of the extracellular matrix. J. Mol. Med., v. 76, n. 3-4, p. 253-65, 1998.

AUMAILLEY, M.; KRIEG, T. Laminins: a family of diverse multifunctional molecules of basement membranes. J. Invest. Dermatol., v. 106, n. 2, p. 209-14, 1996.

BARBARESHI, M. et al. High syndecan-1 expression in breast carcinoma is related to an aggressive phenotype and to poorer prognosis. Cancer, v. 98, n. 3, p. 474-83, 2003.

BATSAKIS, J. G. The pathology of head and neck tumors: nasal cavity and paranasal sinuses, part 5. Head Neck Surg., v. 2, n. 5, p. 410-9, 1980.

BAYER-GARNER, I. B. et al. Syndecan-1 expression is decreased with increasing aggressiveness of basal cell carcinoma. Am. J. Dermatopathol., v. 22, n. 2, p. 119-22, 2000.

BEAUVAIS, D. M. et al. The syndecan-1 ectodomain regulates alphaVbeta3 integrin activity in human mammary carcinoma cells. J. Cell Biol., v. 167, n. 1, p. 171-81, 2004.

BEAUVAIS, D. M.; RAPRAEGER, A. C. Syndecan-1-mediated cell spreading requires signaling by alphavbeta3 integrins in human breast carcinoma cells. Exp. Cell Res., v. 286, n. 2, p. 219-32, 2003.

BERDITCHEVSKI, F. Complexes of tetraspanins with integrins: more than meets the eye. J. Cell Sci., v. 114, p. 4143-51, 2001, Pt. 23.

BERGERS, G. et al. Matrix metalloproteinase- 9 triggers the angiogenic switch during carcinogenesis. Nat. Cell Biol., v. 2, n. 10, p. 737-44, 2000.

${ }^{*}$ De acordo com:

ASSOCIAÇÃO BRASILEIRA DE NORMAS TÉCNICAS. NBR 6023: Informação e documentação: referências: elaboração. Rio de Janeiro, 2002. 
BERNFIELD, M. et al. Biology of the syndecans: a family of transmembrane heparan sulfate proteoglycans. Annu. Rev. Cell Biol., v. 8, p. 365-93, 1992.

BERNFIELD, M. et al. Functions of cell surface heparan sulfate proteoglycans. Annu. Rev. Biochem., v. 68, p. 729-777, 1999.

BIANCHI, B. et al. Adenoid cystic carcinoma of intraoral minor salivary glands. Oral Oncol., 2008. In press.

BIRK, D. E. et al. Collagen fibrillogenesis in situ: fibril segments become long fibrils as the developing tendon matures. Dev. Dyn., v. 208, n. 3, p. 291-8, 1997.

BJORKLUND, M.; KOIVUNEN, E. Gelatinase-mediated migration and invasion of cancer cells. Biochim. Biophys. Acta, v. 1755, n. 1, p. 37-69, 2005.

BORG, T. K. It's the matrix! ECM, proteases, and cancer. Am. J. Pathol., v. 164, n. 4, p. 1141-2, 2004.

BORNSTEIN, P.; SAGE, E. H. Matricellular proteins: extracellular modulators of cell function. Curr. Opin. Cell Biol., v. 14, n. 5, p. 608-16, 2002.

BOSMAN, F. T.; STAMENKOVIC, I. Functional structure and composition of the extracellular matrix. J. Pathol., v. 200, n. 4, p. 423-8, 2003.

BRICKMAN, Y. G. et al. Heparan sulfates mediate the binding of basic fibroblast growth factor to a specific receptor on neural precursor cells. J. Biol. Chem., v. 270, n. 42, p. 24941-8, 1995.

BUCCIONE, R. et al. Foot and mouth: podosomes, invadopodia and circular dorsal ruffles. Nat. Rev. Mol. Cell Biol., v. 5, n. 8, p. 647-57, 2004.

BURBACH, B. J. et al. Syndecan-1 ectodomain regulates matrix-dependent signaling in human breast carcinoma cells. Exp. Cell Res., v. 300, n. 1, p. 234-47, 2004.

BURGESON, R. E. et al. A new nomenclature for the laminins. Matrix Biol., V. 14, n. 3, p. 209-11, 1994.

CALDERWOOD, D. A. et al. The Talin head domain binds to integrin beta subunit cytoplasmic tails and regulates integrin activation. J. Biol. Chem., v. 274, n. 40, p. 28071-4, 1999.

CAPUANO, A. C.; JAEGER, R. G. The effect of laminin and its peptide SIKVAV on a human salivary gland myoepithelioma cell line. Oral Oncol., v. 40, n. 1, p. 36-42, 2004. 
CATTARUZZA, S.; PERRIS, R. Approaching the proteoglycome: molecular interactions of proteoglycans and their functional output. Macromol. Biosci., v. 6, n. 8, p. 667-80, 2006.

CHAKRAVARTI, R. et al. Functional role of syndecan-1 cytoplasmic V region in lamellipodial spreading, actin bundling, and cell migration. Mol. Biol. Cell, v. 16, n. 8, p. 3678-91, 2005.

CHAMBERS, A. F.; MATRISIAN, L. M. Changing views of the role of matrix metalloproteinases in metastasis. J. Natl. Cancer Inst., v. 89, n. 17, p. 1260-70, 1997.

CHANG, C.; WERB, Z. The many faces of metalloproteases: cell growth, invasion, angiogenesis and metastasis. Trends Cell Biol., v. 11, n. 11, p. S37-43, 2001.

CHANG, Z. et al. Differential ability of heparan sulfate proteoglycans to assembly the fibroblast growth factor receptor complex in situ. Faseb J., v.14, n. 1, p.137-144, 2000.

CHARONIS, A. S. et al. A novel synthetic peptide from the B1 chain of laminin with heparin-binding and cell adhesion-promoting activities. J. Cell Biol., v. 107, n. 3, p. 1253-60, 1988.

CHAUDHRY, A. P. et al. Histogenesis of adenoid cystic carcinoma of the salivary glands. Light and electronmicroscopic study. Cancer, v. 58, n. 1, p. 72-82, 1986.

CHEN, D. et al. Syndecan-1 expression in locally invasive and metastatic prostate cancer. Urology, v. 63, n. 2, p. 402-7, 2004.

CHENG, J. et al. Biosynthesis of basement membrane molecules by salivary adenoid cystic carcinoma cells: an immunofluorescence and confocal microscopic study. Virchows Arch., v. 426, n. 6, p. 577-86, 1995.

CHENG, J. et al. Basement membranes in adenoid cystic carcinoma. An immunohistochemical study. Cancer, v. 69, n. 11, p. 2631-40, 1992.

CHOMETTE, G. et al. Adenoid cystic carcinoma of minor salivary glands. Analysis of 86 cases. Clinico-pathological, histoenzymological and ultrastructural studies. Virchows Arch. A. Pathol. Anat. Histol., v. 395, n. 3, p. 289-301, 1982.

CHUNG, A. E. et al. Properties of a basement membrane-related glycoprotein synthesized in culture by a mouse embryonal carcinomaderived cell line. Cell, v. 16, n. 2, p. 277-87, 1979.

COLOGNATO-PYKE, H. et al. Mapping of network-forming, heparin-binding, and alpha 1 beta 1 integrin-recognition sites within the alpha-chain short arm of laminin-1. J. Biol. Chem., v. 270, n. 16, p. 9398-406, 1995. 
COLOGNATO, H.; YURCHENCO, P. D. Form and function: the laminin family of heterotrimers. Dev. Dyn., v. 218, n. 2, p. 213-34, 2000.

COMOGLIO, P. M.; TRUSOLINO, L. Cancer: the matrix is now in control. Nat. Med., v. 11, n. 11, p. 1156-9, 2005.

CONEJO, J. R. et al. Syndecan-1 expression is up-regulated in pancreatic but not in other gastrointestinal cancers. Int. J. Cancer, v. 88, n. 1, p. 12-20, 2000.

COOPER, A. R. et al. Studies on the biosynthesis of laminin by murine parietal endoderm cells. Eur. J. Biochem., v. 119, n. 1, p. 189-97, 1981.

COPPOLINO, M. G.; DEDHAR, S. Bi-directional signal transduction by integrin receptors. Int. J. Biochem. Cell Biol., v. 32, n. 2, p. 171-88, 2000.

CORCORAN, M. L. et al. Laminin SIKVAV peptide induction of monocyte/macrophage prostaglandin E2 and matrix metalloproteinases. J. Biol. Chem., v. 270, n. 18, p. 10365-8, 1995.

D'ARDENNE, A. J. et al. Laminin and fibronectin in adenoid cystic carcinoma. J. Clin. Pathol., v. 39, n. 2, p. 138-44, 1986.

DARDICK, I. Salivary Gland Tumor Pathology. New York: Igaku-Shoin, 1996.

DAVIDSON, B. et al. Coordinated expression of integrin subunits, matrix metalloproteinases (MMP), angiogenic genes and Ets transcription factors in advanced-stage ovarian carcinoma: a possible activation pathway? Cancer Metastasis Rev., v. 22, n. 1, p. 103-15, 2003.

DAVIS, G. E. et al. Regulation of tissue injury responses by the exposure of matricryptic sites within extracellular matrix molecules. Am. J. Pathol., v. 156, n. 5, p. 1489-98, 2000.

DE MELKER, A. A.; SONNENBERG, A. Integrins: alternative splicing as a mechanism to regulate ligand binding and integrin signaling events. Bioessays, v. 21, n. 6, p. 499-509, 1999.

DE OLIVEIRA, P. T. et al. The effect of a reconstituted basement membrane (matrigel) on a human salivary gland myoepithelioma cell line. Virchows Arch., v. 439, n. 4, p. 571-8, 2001.

DEDHAR, S.; HANNIGAN, G. E. Integrin cytoplasmic interactions and bidirectional transmembrane signalling. Curr. Opin. Cell Biol., v. 8, n. 5, p. 657-69, 1996.

EGEBLAD, M.; WERB, Z. New functions for the matrix metalloproteinases in cancer progression. Nat. Rev. Cancer, v. 2, n. 3, p. 161-74, 2002. 
EKBLOM, M. et al. Laminin isoforms and epithelial development. Ann. N. Y. Acad. Sci., v. 857, p. 194-211, 1998.

EKBLOM, P. Extracellular matrix and cell adhesion molecules in nephrogenesis. Exp. Nephrol., v. 4, n. 2, p. 92-6, 1996.

EKBLOM, P. et al. Role of mesenchymal nidogen for epithelial morphogenesis in vitro. Development, v. 120, n. 7, p. 2003-14, 1994.

EKBLOM, P. et al. Expression and biological role of laminin-1. Matrix Biol., v. 22, n. 1, p. 35-47, 2003.

ELENIUS, K. et al. Induced expression of syndecan in healing wounds. J. Cell Biol., v. 114, n. 3, p. 585-95, 1991.

EL-NAGGAR, A. K.; HUVOS, A. G. Salivary Glands - Adenoid Cystic Carcinoma. In: BARNES, L. et al. (Ed.). World Health Organization Classification of Tumours. Pathology and Genetics of Head and Neck Tumours. Lyon: IARC Press, 2005. p. 221-22.

ENGBRING, J. A. et al. The B16F10 cell receptor for metastasis-promoting site on laminin-1 is a heparan sulfate/chondroitin sulfate-containing proteoglycan. Cancer Res., v. 62, n. 12, p. 3549-54, 2002.

ETHUNANDAN, M. et al. Primary epithelial submandibular salivary gland tumours - Review of management in a district general hospital setting. Oral Oncol., 2008. In press.

EVERSOLE, L. R. Histogenic classification of salivary tumors. Arch. Pathol., v. 92, n. 6, p. 433-43, 1971.

FAISAL KHAN, K. M. et al. Exposure of cryptic domains in the alpha 1-chain of laminin-1 by elastase stimulates macrophages urokinase and matrix metalloproteinase-9 expression. J. Biol. Chem., v. 277, n. 16, p. 13778-86, 2002.

FRANCA, C. M. et al. The role of basement membrane proteins on the expression of neural cell adhesion molecule (N-CAM) in an adenoid cystic carcinoma cell line. Oral Oncol., v. 36, n. 2, p. 248-52, 2000.

FRANCA, C. M. et al. Effect of N-CAM on in vitro invasion of human adenoid cystic carcinoma cells. Oral Oncol., v. 37, n. 8, p. 638-42, 2001.

FREITAS, V. M.; JAEGER, R. G. The effect of laminin and its peptide SIKVAV on a human salivary gland adenoid cystic carcinoma cell line. Virchows Arch., v. 441, n. 6, p. 569-76, 2002. 
FREITAS, V. M. et al. Laminin-1 and SIKVAV a laminin-1-derived peptide, regulate the morphology and protease activity of a human salivary gland adenoid cystic carcinoma cell line. Oral Oncol., v. 40, n. 5, p. 483-9, 2004.

FREITAS, V. M. et al. SIKVAV, a laminin alpha1-derived peptide, interacts with integrins and increases protease activity of a human salivary gland adenoid cystic carcinoma cell line through the ERK 1/2 signaling pathway. Am. J. Pathol., v. 171, n. 1, p. 124-38, 2007.

FRIEDMAN, E. W.; SCHWARTZ, A. E. Diagnosis of salivary gland tumors. CA Cancer J. Clin., v. 24, n. 5, p. 266-73, 1974.

FRIEDRICHS, K. et al. High expression level of alpha 6 integrin in human breast carcinoma is correlated with reduced survival. Cancer Res., v. 55, n. 4, p. 901-6, 1995.

FUJIYA, M. et al. Reduced expression of syndecan-1 affects metastatic potential and clinical outcome in patients with colorectal cancer. Jpn. J. Cancer Res., v. 92, n. 10, p. 1074-81, 2001.

GAMA-DE-SOUZA, L. N. Peptídeo C16 derivado da laminina regula migração, invasão e secreção de protease em linhagem celular derivada de carcinoma adenóide cístico humano através de integrinas e das vias e sinalização AKT e ERK. $123 \mathrm{f}$. Tese (Doutorado em Biologia Celular e do Desenvolvimento) - Instituto de Ciências Biomédicas, Universidade de São Paulo, São Paulo, 2009.

GARDEN, A. S. et al. The influence of positive margins and nerve invasion in adenoid cystic carcinoma of the head and neck treated with surgery and radiation. Int. J. Radiat. Oncol. Biol. Phys., v. 32, n. 3, p. 619-26, 1995.

GHOSH, S.; STACK, M. S. Proteolytic modification of laminins: functional consequences. Microsc. Res. Tech., v. 51, n. 3, p. 238-46, 2000.

GIANCOTTI, F. G.; TARONE, G. Positional control of cell fate through joint integrin/receptor protein kinase signaling. Annu. Rev. Cell Dev. Biol., v. 19, p. 173-206, 2003.

GLEAVE, M. et al. Epidermal growth factor receptor-mediated autocrine and paracrine stimulation of human transitional cell carcinoma. Cancer Res., v. 53, n. 21, p. 5300-7, 1993.

GOSPODAROWICZ, D.; CHENG, J. Heparin protects basic and acidic FGF from inativation. J. Cell. Physiol., v. 128, n. 3, p. 475-84, 1986.

GÖTTE, M. Syndecans in inflammation. Faseb J., v. 17, n. 6, p. 575-91, 2003. 
GRAF, J. et al. A pentapeptide from the laminin B1 chain mediates cell adhesion and binds the 67,000 laminin receptor. Biochemistry, v. 26, n. 22, p. 6896-900, 1987.

GRANT, D. S. et al. Interaction of endothelial cells with a laminin A chain peptide (SIKVAV) in vitro and induction of angiogenic behavior in vivo. J. Cell Physiol., v. 153, n. 3, p. 614-25, 1992.

GROSS, J.; LAPIERE, C. M. Collagenolytic activity in amphibian tissues: a tissue culture assay. Proc. Natl. Acad. Sci. USA, v. 48, p. 1014-22, 1962.

GUDJONSSON, T. et al. Normal and tumor-derived myoepithelial cells differ in their ability to interact with luminal breast epithelial cells for polarity and basement membrane deposition. J. Cell Sci., v. 115, p. 39-50, 2002, Pt. 1.

HANDSLEY, M. M.; EDWARDS, D. R. Metalloproteinases and their inhibitors in tumor angiogenesis. Int. J. Cancer, v. 115, n. 6, p. 849-60, 2005.

HARADA, K. et al. Reduced expression of syndecan-1 correlates with histologic dedifferentiation, lymph node metastasis, and poor prognosis in intrahepatic cholangiocarcinoma. Hum. Pathol., v. 34, n. 9, p. 857-63, 2003.

HAYASHI, K. et al. Immunocytochemistry of cell surface heparan sulfate proteoglycan in mouse tissues. A light and electron microscopy study. J. Histochem. Cytohem., v. 35, n. 10, p. 1079-88, 1987.

HOFFMAN, M. P. et al. Role of laminin-1 and TGF-beta 3 in acinar differentiation of a human submandibular gland cell line (HSG). J. Cell Sci., v. 109, Pt. 8, p. 2013-21, 1996.

HOFFMAN, M. P. et al. Laminin-1 and laminin-2 G-domain synthetic peptides bind syndecan-1 and are involved in acinar formation of a human submandibular gland cell line. J. Biol. Chem., v. 273, n. 44, p. 28633-41, 1998.

HOFFMAN, M. P. et al. Cell type-specific differences in glycosaminoglycans modulate teh biological activity of a heparn-biding peptide (RKRLQVQLSIRT) from the G domain of the laminin $\alpha 1$ chain. J. Biol. Chem., v.276, n. 25, p. 22077-85, 2001.

HOZUMI, K. et al. Laminin $\alpha 1$ chain LG4 module promotes cell attachment through syndecans and cell spreading through integrin $\alpha 2 \beta 1$. J. Biol. Chem., v. 281, n. 43, p. 32929-40, 2006.

HUANG, M. et al. Factors influencing survival rate in adenoid cystic carcinoma of the salivary glands. Int. J. Oral Maxillofac. Surg., v. 26, n. 6, p. 435-9, 1997. 
HUMPHRIES, M. J. Integrin activation: the link between ligand binding and signal transduction. Curr. Opin. Cell Biol., v. 8, n. 5, p. 632-40, 1996.

HUMPHRIES, M. J. et al. Integrin-syndecan cooperation governs the assembly of signalling complexes during cell spreading. Novartis Found. Symp., v. 269, p. 178-88, 2005, Discussion188-92, 223-130.

HUTTENLOCHER, A. et al. Adhesion in cell migration. Curr. Opin. Cell Biol., v. 7, n. 5, p. 697-706, 1995.

HYNES, R. O. Integrins: a family of cell surface receptors. Cell, v. 48, n. 4, p. 549-54, 1987.

HYNES, R. O. Integrins: versatility, modulation, and signaling in cell adhesion. Cell, v. 69, n. 1, p. 11-25, 1992.

HYNES, R. O. Cell adhesion: old and new questions. Trends Cell Biol., v. 9, n. 12, p. M33-7, 1999.

HYNES, R. O. Integrins: bidirectional, allosteric signaling machines. Cell, v. 110 , n. 6, p. 673-87, 2002.

HYNES, R. O. Structural biology. Changing partners. Science, v. 300, n. 5620, p. 755-6, 2003.

IKEMOTO, S. et al. Laminin peptide-conjugated chitosan membrane: Application for keratinocyte delivery in wounded skin. J. Biomed. Mater. Res. A, v. 79, n. 3, p. 716-22, 2006.

INKI, P. et al. Association between syndecan-1 expression and clinical outcome in squamous cell carcinoma of the head and neck. Br. J. Cancer, v. 70, n. 2, p. 319-23, 1994.

IOZZO, R. V. Matrix proteoglycans: from molecular design to cellular function. Annu. Rev. Biochem., v. 67, p. 609-52, 1998.

ITO, F. A. et al. Salivary gland tumors in a Brazilian population: a retrospective study of 496 cases. Int. J. Oral Maxillofac. Surg., v. 34, n. 5, p. 533-6, 2005.

IWAMOTO, Y. et al. Synthetic pentapeptide from the B1 chain of laminin promotes B16F10 melanoma cell migration. J. Cell Physiol., v. 134, n. 2, p. 287-91, 1988.

IWAMOTO, Y. et al. YIGSR, a synthetic laminin pentapeptide, inhibits experimental metastasis formation. Science, v. 238, n. 4830, p. 1132-4, 1987. 
JAEGER, M. M. et al. Effect of spatial arrangement of the basement membrane on cultured pleomorphic adenoma cells. Study by immunocytochemistry and electron and confocal microscopy. Virchows Arch., v. 430, n. 6, p. 467-77, 1997.

JAEGER, R. G. et al. Expression of smooth-muscle actin in cultured cells from human plasmacytoid myoepithelioma. Oral Surg. Oral Med. Oral Pathol. Oral Radiol. Endod., v. 84, n. 6, p. 663-7, 1997.

JAEGER, R. G. et al. Secretion of collagen I and tenascin is modulated by laminin-111 in 3D culture of human adenoid cystic carcinoma cells. Int. J. Exp. Pathol., v. 89, n. 2, p. 98-105, 2008.

KADLER, K. E. et al. Collagen fibril formation. Biochem. J., v. 316, p. 1-11, 1996.

KADOYA, $Y$. et al. Laminin alpha1 chain $G$ domain peptide, RKRLQVQLSIRT, inhibits epithelial branching morphogenesis of cultured embryonic mouse submandibular gland. Dev. Dyn., v. 212, n. 3, p. 394-402, 1998.

KADOYA, Y. et al. Role for laminin-alpha5 chain LG4 module in epithelial branching morphogenesis. Dev. Biol., v. 263, n. 1, p. 153-64, 2003.

KADOYA, Y.; YAMASHINA, S. Salivary gland morphogenesis and basement membranes. Anat. Sci., v. 80, n. 2, p. 71-9, 2005.

KAMAL, M. M. et al. Cytodiagnosis of dermal cylindroma. Acta Cytol., v. 40, n. 2, p. 375-6, 1996.

KANEMOTO, T. et al. Identification of an amino acid sequence from the laminin A chain that stimulates metastasis and collagenase IV production. Proc. Natl. Acad. Sci. USA, v. 87, n. 6, p. 2279-83, 1990.

KHAN, K. M.; FALCONE, D. J. Role of laminin in matrix induction of macrophage urokinase-type plasminogen activator and 92-kDa metalloproteinase expression. J. Biol. Chem., v. 272, n. 13, p. 8270-5, 1997.

KIBBEY, M. C. et al. Role of the SIKVAV site of laminin in promotion of angiogenesis and tumor growth: an in vivo Matrigel model. J. Natl. Cancer Inst., v. 84, n. 21, p. 1633-8, 1992.

KIM, C. W. et al. Members of the syndecan family of heparan sulfate proteoglycans are expressed in distinct cell-, tissue-, and developmentspecific patterns. Mol. Biol. Cell, v. 5, n. 7, p. 797-805, 1994.

KLEINMAN, H. K.; MARTIN, G. R. Matrigel: basement membrane matrix with biological activity. Semin. Cancer Biol., v. 15, n. 5, p. 378-86, 2005. 
KLEINMAN, H. K. et al. Formation of a supramolecular complex is involved in the reconstitution of basement membrane components. Biochemistry, v. 22, n. 21, p. 4969-74, 1983.

KLEINMAN, H. K. et al. Role of the extracellular matrix in morphogenesis. Curr. Opin. Biotechnol., v. 14, n. 5, p. 526-32, 2003.

KURATOMI, Y. et al. Laminin gamma 1 chain peptide, C-16 (KAFDITYVRLKF), promotes migration, MMP-9 secretion, and pulmonary metastasis of B16-F10 mouse melanoma cells. Br. J. Cancer, v. 86, n. 7, p. 1169-73, 2002.

KUTLESA, S. et al. Developmentally regulated interactions of human thymocytes with different laminin isoforms. Immunology, v. 105, n. 4, p. 407-18, 2002.

LAM, K. Y.; YUEN, A. P. Cancer of the larynx in Hong Kong: a clinicopathological study. Eur. J. Surg. Oncol., v. 22, n. 2, p. 166-70, 1996.

LEE, M. H.; MURPHY, G. Matrix metalloproteinases at a glance. J. Cell Sci., v. 117, p. 4015-6, 2004, Pt. 18.

LIOTTA, L. A. Molecular biology of metastases: a review of recent approaches. Eur. J. Cancer Clin. Oncol., v. 22, n. 3, p. 345-8, 1986.

$\mathrm{LOH}, \mathrm{K}$. S. et al. Prognostic factors in malignancy of the minor salivary glands. Head Neck, v. 31, n. 1, p. 58-63, 2009.

LOYOLA, A. M. et al. Minor salivary gland tumours. A retrospective study of 164 cases in a Brazilian population. Eur. J. Cancer B. Oral Oncol., v. 31B, n. 3, p. 197-201, 1995.

LUGASSY, C. et al. Angio-tumoral complex in human malignant melanoma characterised by free laminin: ultrastructural and immunohistochemical observations. J. Submicrosc. Cytol. Pathol., v. 29, n. 1, p. 19-28, 1997.

LUNDIN, M. et al. Epithelial syndecan-1 expression is associated with stage and grade in colorectal cancer. Oncology, v. 68, n. 4-6, p. 306-13, 2005.

LUNDQVIST, K.; SCHMIDTCHEN, A. Immunohistochemical studies on proteoglycan expression in normal skin and chronic ulcers. Br. J. Dermatol., v. 144, n. 2, p. 254-9, 2001.

LYNCH, C. C.; MATRISIAN, L. M. Matrix metalloproteinases in tumor-host cell communication. Differentiation, v. 70, n. 9-10, p. 561-73. 2002.

MACIEJEWSKI, A. et al. Outcome of surgery for adenoid cystic carcinoma of head and neck region. J. Craniomaxillofac. Surg., v. 30, n. 1, p. 59-61, 2002. 
MAEDA, T. et al. Induction of syndecan-1 expression in stromal fibroblasts promotes proliferation of human breast cancer cells. Cancer Res., v. 64, n. 2, p. 612-621, 2004.

MAEDA, T. et al. Syndecan-1 expression by stromal fibroblasts promotes breast carcinoma growth in vivo and stimulates tumor angiogenesis. Oncogene, v. 25, n. 9, p. 1408-12, 2006.

MALINDA, K. M.; KLEINMAN, H. K. The laminins. Int. J. Biochem. Cell Biol., v. 28, n. 9, p. 957-9, 1996.

MARSHALL, L. J. et al. Plasminogen activator inhibitor-1 supports IL-8mediated neutrophil transendothelialmigration by inhibition of the constutive shedding of endothelial IL-8/heparan sulfate/syndecan-1 complexes. J. Immunol., v. 171, n. 4, p. 2057-65, 2003.

MARTIN, G. R. et al. The regulation of basement membrane formation and cell-matrix interactions by defined supramolecular complexes. Ciba Found. Symp., v. 108, p. 197-212, 1984.

MARTIN, G. R.; TIMPL, R. Laminin and other basement membrane components. Annu. Rev. Cell Biol., v. 3, p. 57-85, 1987.

MCCAWLEY, L. J.; MATRISIAN, L. M. Matrix metalloproteinases: they're not just for matrix anymore! Curr. Opin. Cell Biol., v. 13, n. 5, p. 534-40, 2001.

MCQUADE, K. J. et al. Sindecan-1 regulates $\alpha \mathrm{V} \beta 5$ integrin activity in B82L fibroblasts. J. Cell Sci., v. 119, p. 2445-56, 2006, Pt. 2.

MELO, E. S. Laminina e seu peptídeo bioativo AG73 como modulador do fenótipo de linhagem celular derivada de carcinoma adenóide cístico humano. $54 \mathrm{f}$. Dissertação (Mestrado em Biologia Celular e Tecidual) - Instituto de Ciências Biomédicas, Universidade de São Paulo, São Paulo, 2004.

MERCURIO, A. M. Laminin receptors: achieving specificity through cooperation. Trends Cell Biol., v. 5, n. 11, p. 419-23, 1995.

MINER, J. H.; YURCHENCO, P. D. Laminin functions in tissue morphogenesis. Annu. Rev. Cell Dev. Biol., v. 20, p. 255-84, 2004.

MIRA, E. et al. Secreted MMP9 promotes angiogenesis more efficiently than constitutive active MMP9 bound to the tumor cell surface. J. Cell Sci., v. 117 , p. 1847-57, 2004, Pt. 9.

MIRANTI, C. K.; BRUGGE, J. S. Sensing the environment: a historical perspective on integrin signal transduction. Nat. Cell Biol., v. 4, n. 4, p. E8390, 2002. 
MITURSKI, R. et al. Immunohistochemical expression of syndecan-1 in human endometrial cancer cells. Int. J. Mol. Med., v. 2, n. 4, p. 397-401, 1998.

MOCHIZUKI, M. et al. Laminin-1 peptide-conjugated chitosan membranes as a novel approach for cell engineering. Faseb J., v. 17, n. 8, p. 875-77, 2003.

MOCHIZUKI, M. et al. Angiogenic activity of syndecan-binding laminin peptide AG73 (RKRLQVQLSIRT). Arch. Biochem. Biophys., v. 459, n. 2, p. 249-55, 2007.

MORAIS FREITAS, V. et al. Malignancy-related 67kDa laminin receptor in adenoid cystic carcinoma. Effect on migration and beta-catenin expression. Oral Oncol., v. 43, n. 10, p. 987-98, 2007.

MORGAN, M. R. et al. The integrin cytoplasmic-tail motif EKQKVDLSTDC is sufficient to promote tumor cell invasion mediated by matrix metalloproteinase (MMP)-2 or MMP-9. J. Biol. Chem., v. 279, n. 25, p. 26533-9, 2004.

MORGAN, M. R. et al. Synergistic control of cell adhesion by integrins and syndecans. Nat. Rev. Mol. Cell Biol., v. 8, n. 12, p. 957-69, 2007.

MOSCATELLI, D.; RIFKIN, D. B. Membrane and matrix localization of proteinases: a common theme in tumor cell invasion and angiogenesis. Biochim. Biophys. Acta, v. 948, n. 1, p. 67-85, 1988.

MOTT, J. D.; WERB, Z. Regulation of matrix biology by matrix metalloproteinases. Curr. Opin. Cell Biol., v. 16, n. 5, p. 558-64, 2004.

MYLIUS, E. A. The identification and the role of the myoepithelial cell in salivary gland tumours. Acta Pathol. Microbiol. Scand. Suppl., v. 50, p. 181,1960 .

MYLLYHARJU, J.; KIVIRIKKO, K. I. Collagens and collagen-related diseases. Ann. Med., v. 33, n. 1, p. 7-21, 2001.

NAGANUMA, H. et al. Quantification of thrombospondin-1 and expression of alphavbeta3 and alpha3beta1 integrins and syndecan-1 as cell-surface receptors for thrombospondin-1 in malignant glioma cells. J. Neurooncol., v. 70, n. 3, p. 309-17, 2004.

NAGASE, H.; WOESSNER, J. F., JR. Matrix metalloproteinases. J. Biol. Chem., v. 274, n. 31, p. 21491-4, 1999.

NAIDET, C. et al. Peptides containing the cell-attachment recognition signal Arg-Gly-Asp prevent gastrulation in Drosophila embryos. Nature, v. 325, n. 6102, p. 348-50, 1987. 
NEVILLE, B. D. et al. Patologia de Glândulas Salivares. In: NEVILLE, B. D. et al. (Ed.). Patologia Oral \& Maxilofacial. Rio de Janeiro: Guanabara Koogan, 2004. p. 314-52.

NOMIZU, M. et al. Identification of cell binding sites in the laminin alpha 1 chain carboxyl-terminal globular domain by systematic screening of synthetic peptides. J. Biol. Chem., v. 270, n. 35, p. 20583-90, 1995.

NOMIZU, M. et al. Cell binding sequences in mouse laminin alpha1 chain. $\mathbf{J}$. Biol. Chem., v. 273, n. 49, p. 32491-9, 1998.

NOMIZU, M. et al. Cell adhesive sequences in mouse laminin beta1 chain. Arch. Biochem. Biophys., v. 378, n. 2, p. 311-20, 2000.

NOMIZU, M. et al. Identification of cell binding sequences in mouse laminin gamma1 chain by systematic peptide screening. J. Biol. Chem., v. 272, n. 51, p. 32198-205, 1997.

NOMIZU, M. et al. The all-D-configuration segment containing the IKVAV sequence of laminin A chain has similar activities to the all-L-peptide in vitro and in vivo. J. Biol. Chem., v. 267, n. 20, p. 14118-21, 1992.

NOMIZU, M. et al. Identification of homologous biologically active sites on the N-terminal domain of laminin alpha chains. Biochemistry, v. 40, n. 50, p. 15310-7, 2001.

NUMA, F. et al. Syndecan-1 expression in cancer of uterine cervix: association with lymph node metastasis. Int. J. Oncol., v. 20, n. 1, p. 39-43, 2002.

NYBERG, P. et al. Endostatin inhibits human tongue carcinoma cell invasion and intravasation and blocks the activation of matrix metalloprotease-2, -9 , and -13. J. Biol. Chem. v. 278, n. 25, p. 22404-11, 2003.

O'TOOLE, T. E. et al. Integrin cytoplasmic domains mediate inside-out signal transduction. J. Cell. Biol., v. 124, n. 6, p. 1047-59, 1994.

OGAWA, T. et al. The short arm of laminin $\gamma 2$ chain of laminin-5 (laminin332 ) binds syndecan- 1 and regulates cellular adhesion and migration by suppressing phosphorylation of integrin $\beta 4$ chain. Mol. Biol. Cell, v. 18, n. 5 , p. 1621-33, 2007.

OLIVEIRA, E. C. Laminina-1 e seu peptídeo AG73 regulando a morfologia e atividade proteolítica de linhagem celular derivada de mioepitelioma humano. $78 \mathrm{f}$. Dissertação (Mestrado em Biologia Celular e do Desenvolvimento) - Instituto de Ciências Biomédicas, Universidade de São Paulo, São Paulo, 2004. 
OSBORN, D. A. Morphology and the natural history of cribriform adenocarcinoma (adenoid cystic carcinoma). J. Clin. Pathol., v. 30, n. 3, p. 195-205, 1977.

OVERALL, C. M.; LOPEZ-OTIN, C. Strategies for MMP inhibition in cancer: innovations for the post-trial era. Nat. Rev. Cancer, v. 2, n. 9, p. 657-72, 2002.

PAGE-MCCAW, A. et al. Matrix metalloproteinases and the regulation of tissue remodelling. Nat. Rev. Mol. Cell Biol., v. 8, n. 3, p. 221-33, 2007.

PARSONS, J. T. et al. Management of minor salivary gland carcinomas. Int. J. Radiat. Oncol. Biol. Phys., v. 35, n. 3, p. 443-54, 1996.

PATARROYO, M. et al. Laminin isoforms in tumor invasion, angiogenesis and metastasis. Semin. Cancer Biol., v. 12, n. 3, p. 197-207, 2002.

PAULSSON, M. Noncollagenous proteins of basement membranes. Coll. Relat. Res., v. 7, n. 6, p. 443-61, 1987.

PETERSON, J. A. et al. Heparin II domain of fibronectin uses alpha4beta1 integrin to control focal adhesion and stress fiber formation, independent of syndecan-4. J. Biol. Chem., v. 280, n. 8, p. 6915-22, 2005.

PFAFF, M. et al. Binding of purified collagen receptors (alpha 1 beta 1 , alpha 2 beta 1) and RGD-dependent integrins to laminins and laminin fragments. Eur. J. Biochem., v. 225, n. 3, p. 975-84, 1994.

PIERSCHBACHER, M. et al. Synthetic peptide with cell attachment activity of fibronectin. Proc. Natl. Acad. Sci. USA, v. 80, n. 5, p. 1224-7, 1983.

PIEZ, K. A. History of extracellular matrix: a personal view. Matrix Biol., v. 16, n. 3, p. 85-92, 1997.

PINHEIRO, J. J. et al. Local invasiveness of ameloblastoma. Role played by matrix metalloproteinases and proliferative activity. Histopathology, v. 45, n. 1, p. 65-72, 2004.

PONCE, M. L. et al. Identification of a potent peptide antagonist to an active laminin-1 sequence that blocks angiogenesis and tumor growth. Cancer Res., v. 63, n. 16, p. 5060-4, 2003.

PONCE, M. L.; KLEINMAN, H. K. Identification of redundant angiogenic sites in laminin alpha1 and gamma1 chains. Exp. Cell Res., v. 285, n. 2, p. 189-95, 2003.

POWELL, S. K.; KLEINMAN, H. K. Neuronal laminins and their cellular receptors. Int. J. Biochem. Cell Biol., v. 29, n. 3, p. 401-14, 1997. 
POWELL, S. K. et al. Laminin-like proteins are differentially regulated during cerebellar development and stimulate granule cell neurite outgrowth in vitro. J. Neurosci. Res., v. 54, n. 2, p. 233-47, 1998.

PRESTA, M. et al. Fibroblast growth factor/fibroblast growth factor receptor system in angiogenesis. Cytokine Growth Factor Rev., v. 16, n. 2, p. 15978, 2005.

PUPA, S. M. et al. New insights into the role of extracellular matrix during tumor onset and progression. J. Cell Physiol., v. 192, n. 3, p. 259-67, 2002.

RAITZ, R. et al. A study of the extracellular matrix in salivary gland tumors. J. Oral Pathol. Med., v. 32, n. 5, p. 290-6, 2003.

REGEZI, J. A.; BATSAKIS, J. G. Histogenesis of salivary gland neoplasms. Otolaryngol. Clin. North Am., v. 10, n. 2, p. 297-307, 1977.

RENEHAN, A. G. et al. Clinico-pathological and treatment-related factors influencing survival in parotid cancer. Br. J. Cancer, v. 80, n. 8, p. 1296300, 1999.

REUNANEN, N. et al. Activation of p38 alpha MAPK enhances collagenase1 (matrix metalloproteinase (MMP)-1) and stromelysin-1 (MMP-3) expression by mRNA stabilization. J. Biol. Chem., v. 277, n. 35, p. 32360-8, 2002.

RIALAS, C. M. et al. Nitric oxide mediates laminin-induced neurite outgrowth in PC12 cells. Exp. Cell Res., v. 260, n. 2, p. 268-76, 2000.

RICHARD, B. L. et al. Identification of synthetic peptides derived from laminin alpha1 and alpha2 chains with cell type specificity for neurite outgrowth. Exp. Cell Res., v. 228, n. 1, p. 98-105, 1996.

ROYCE, L. S. et al. Induction of an invasive phenotype in benign tumor cells with a laminin A-chain synthetic peptide. Invasion Metastasis, v. 12, n. 3-4, p. 149-55, 1992.

RUNDHAUG, J. E. Matrix metalloproteinases and angiogenesis. J. Cell Mol. Med., v. 9, n. 2, p. 267-85, 2005.

RUOSLAHTI, E.; PIERSCHBACHER, M. D. Arg-Gly-Asp: a versatile cell recognition signal. Cell, v. 44, n. 4, p. 517-8, 1986.

SAKU, T. et al. Immunolocalization of basement membrane molecules in the stroma of salivary gland pleomorphic adenoma. J. Oral Pathol. Med., v. 19, n. 5, p. 208-14. 1990.

SASAKI, T. et al. Laminin: the crux of basement membrane assembly. J. Cell Biol., v. 164, n. 7, p. 959-63, 2004. 
SCHEELE, S. et al. Laminin isoforms in development and disease. J. Mol. Med., v. 85, n. 8, p. 825-36, 2007.

SCHENK, S.; QUARANTA, V. Tales from the crypt[ic] sites of the extracellular matrix. Trends Cell Biol., v. 13, n. 7, p. 366-75, 2003.

SCHNAPER, H. W. et al. Role of laminin in endothelial cell recognition and differentiation. Kidney Int., v. 43, n. 1, p. 20-5, 1993.

SEBESTYEN, A. et al. Syndecan-1-dependent homotypic cell adhesion in HT58 lymphoma cells. Tumour Biol., v. 21, n. 6, p. 349-57, 2000.

SEIFERT, G.; SOBIN, L. H. The World Health Organization's Histological Classification of Salivary Gland Tumors. A commentary on the second edition. Cancer, v. 70, n. 2, p. 379-85, 1992.

SHINTANI, S. et al. Extracellular matrices expression in invasion area of adenoid cystic carcinoma of salivary glands. Cancer Lett., v. 116, n. 1, p. 914, 1997.

SHINYO, Y. et al. Loss of cell-surface heparan sulfate expression in both cervical intraepithelial neoplasm and invasive cervical cancer. Gynecol. Oncol., v. 96, n. 3, p. 776-83, 2005.

SIMPSON, J. R. et al. Adenoid cystic salivary gland carcinoma: treatment with irradiation and surgery. Radiology, v. 151, n. 2, p. 509-12, 1984.

SKUBITZ, A. P. et al. Definition of a sequence, RYVVLPR, within laminin peptide F-9 that mediates metastatic fibrosarcoma cell adhesion and spreading. Cancer Res., v. 50, n. 23, p. 7612-22, 1990.

SONG, S. Y. et al. Liver metastasis formation by laminin-1 peptide (LQVQLSIRT)-adhesion selected B16-F10 melanoma cells. Int. J. Cancer, v. 71, n. 3, p. 436-41, 1997.

SONNENBERG, A. et al. Integrin recognition of different cell-binding fragments of laminin (P1, E3, E8) and evidence that alpha 6 beta 1 but not alpha 6 beta 4 functions as a major receptor for fragment E8. J. Cell Biol., v. 110, n. 6, p. 2145-55, 1990.

STAMENKOVIC, I. Extracellular matrix remodelling: the role of matrix metalloproteinases. J. Pathol., v. 200, n. 4, p. 448-64, 2003.

STERNLICHT, M. D.; WERB, Z. How matrix metalloproteinases regulate cell behavior. Annu. Rev. Cell Dev. Biol., v. 17, p. 463-516, 2001.

STICKENS, D. et al. Altered endochondral bone development in matrix metalloproteinase 13-deficient mice. Development, v. 131, n. 23, p. 588395, 2004. 
SUBHASHRAJ, K. Salivary gland tumors: a single institution experience in India. Br. J. Oral Maxillofac. Surg., v. 46, n. 8, p. 635-8, 2008.

SUN, H. et al. Omega-3 polyunsaturated fatty acids regulate syndecan-1 expression in human breast cancer cells. Cancer Res., v. 65, n. 10, p. 4442-7, 2005.

SUNG, U. et al. Cell and heparin binding in the distal long arm of laminin: identification of active and cryptic sites with recombinant and hybrid glycoprotein. J. Cell Biol., v. 123, n. 5, p. 1255-68, 1993.

SUZUKI, N. et al. Functional sites in the laminin alpha chains. Connect. Tissue Res., v. 46, n. 3, p. 142-52, 2005.

SWASH, M. Invasion of cranial nerves by salivary cylindroma: four cases treated by radiotherapy. J. Neurol. Neurosurg. Psychiatr., v. 34, n. 4, p. 475-80, 1971.

TAMKUN, J. W. et al. Structure of integrin, a glycoprotein involved in the transmembrane linkage between fibronectin and actin. Cell, v. 46, n. 2, p. 271-82, 1986.

TASHIRO, K. et al. A synthetic peptide containing the IKVAV sequence from the A chain of laminin mediates cell attachment, migration, and neurite outgrowth. J. Biol. Chem., v. 264, n. 27, p. 16174-82, 1989.

THORSEN, F.; TYSNES, B. B. Brain tumor cell invasion, anatomical and biological considerations. Anticancer Res., v. 17, n. 6B, p. 4121-6, 1997.

TIMPL, R. Macromolecular organization of basement membranes. Curr. Opin. Cell Biol., v. 8, n. 5, p. 618-24, 1996.

TIMPL, R.; BROWN, J. C. The laminins. Matrix Biol., v. 14, n. 4, p. 275-81, 1994.

TIMPL, R.; BROWN, J. C. Supramolecular assembly of basement membranes. Bioessays, v. 18, n. 2, p. 123-32, 1996.

TIMPL, R. et al. Characterization of pepsin fragments of basement membrane collagen obtained from a mouse tumor. Eur. J. Biochem., v. 95, n. 2, p. 255-63, 1979.

TIMPL, R. et al. Immunochemical study on basement membrane (type IV) collagens. Immunology, v. 38, n. 1, p. 109-16, 1979.

TIMPL, R. et al. Identification of a new basement membrane collagen by the aid of a large fragment resistant to bacterial collagenase. FEBS Lett., v. 101 , n. 2, p. 265-8, 1979. 
TIMPL, R. et al. Laminin--a glycoprotein from basement membranes. J. Biol. Chem., v. 254, n. 19, p. 9933-7, 1979.

TIMPL, R. et al. Structure and function of laminin LG modules. Matrix Biol., v. 19 , n. 4 , p. $309-17,2000$.

TSANOU, E. et al. Clinicopathological study of the expression of syndecan-1 invasive breast carcinomas. Correletion with extracellular matrix components. J. Exp. Clin. Cancer Res., v. 23, n. 4, p. 641-50, 2004.

TUMOVA, S. et al. Heparan sulfate proteoglycans on the cell surface: versatile coordinators of cellular functions. Int. J. Biochem. Cell Biol., v. 32, n. 3, p. 269-88, 2000.

TUNGGAL, L. et al. Defective laminin 5 processing in cylindroma cells. Am. J. Pathol., v. 160, n. 2, p. 459-68, 2002.

UENO, M. et al. Structural characterization $\mathrm{f}$ heparan sulfate and chondroitin sulfate of syndecan-1 purified from normal murine mammary gland epithelial cells. Common phosphorylation of xylose and differential sulfation of glactose in the protein linkage region tetrasaccharide sequence. J. Biol. Chem., v. 276, n. 31, p. 29134-40, 2001.

VAN DER WAL, J. E. et al. Intraoral adenoid cystic carcinoma. The presence of perineural spread in relation to site, size, local extension, and metastatic spread in 22 cases. Cancer, v. 66, n. 9, p. 2031-33, 1990.

VIHINEN, P.; KAHARI, V. M. Matrix metalloproteinases in cancer: prognostic markers and therapeutic targets. Int. J. Cancer, v. 99, n. 2, p. 157-66, 2002.

VIRTANEN, I. et al. Laminin alpha1-chain shows a restricted distribution in epithelial basement membranes of fetal and adult human tissues. Exp. Cell Res., v. 257, n. 2, p. 298-309, 2000.

VISSE, R.; NAGASE, H. Matrix metalloproteinases and tissue inhibitors of metalloproteinases: structure, function, and biochemistry. Circ. Res., v. 92, n. 8, p. 827-39, 2003.

VOGEL, V. Mechanotransduction involving multimodular proteins: converting force into biochemical signals. Annu. Rev. Biophys. Biomol. Struct., v. 35, p. 459-88, 2006.

VU, T. H. Don't mess with the matrix. Nat. Genet., v. 28 , n. 3, p. 202-3, 2001.

WEEKS, B. S. et al. Laminin-1 and the RKRLQVQLSIRT laminin-1 alpha1 globular domain peptide stimulate matrix metalloproteinase secretion by PC12 cells. Exp. Cell Res., v. 243, n. 2, p. 375-82, 1998. 
WEEKS, B. S. et al. The role of protein kinase $C$ in laminin-mediated neurite outgrowth. Biochem. Biophys. Res. Commun., v. 256, n. 1, p. 98-103, 1999.

WISEMAN, B. S. et al. Site-specific inductive and inhibitory activities of MMP-2 and MMP-3 orchestrate mammary gland branching morphogenesis. J. Cell Biol., v. 162, n. 6, p. 1123-33, 2003.

WOESSNER, J. F., JR. Matrix metalloproteinases and their inhibitors in connective tissue remodeling. Faseb J., v. 5, n. 8, p. 2145-54, 1991.

WOESSNER, J. F., JR. MMPs and TIMPs. An historical perspective. Methods Mol. Bio.I, v. 151, p. 1-23, 2001.

WOESSNER, J. F., JR. MMPs and TIMPs--an historical perspective. Mol. Biotechnol., v. 22, n. 1, p. 33-49, 2002.

WONG, J. Y. et al. Direct measurement of a tethered ligand-receptor interaction potential. Science, v. 275, n. 5301, p. 820-2, 1997.

WOODLEY, D. T. et al. Interactions of basement membrane components. Biochim. Biophys. Acta, v. 761, n. 3, p. 278-83, 1983.

YAMASHITA, $\mathrm{H}$. et al. Cryptic fragment alpha4 LG4-5 derived from laminin alpha4 chain inhibits de novo adipogenesis by modulating the effect of fibroblast growth factor-2. Dev. Growth Differ., v. 50, n. 2, p. 97-107, 2008.

YOKOYAMA, F. et al. Bifunctional peptides derived from homologous loop regions in the laminin alpha chain LG4 modules interact with both alpha 2 beta 1 integrin and syndecan-2. Biochemistry, v. 44, n. 28, p. 9581-9, 2005.

YOSHIDA, Y. et al. Role of laminin in ovarian cancer tumor growth and metastasis via regulation of Mdm2 and Bcl-2 expression. Int. J. Oncol., v. 18, n. 5, p. 913-21, 2001.

YURCHENCO, P. D. Assembly of basement membranes. Ann. N. Y. Acad. Sci., v. 580, p. 195-213, 1990.

YURCHENCO, P. D. et al. Basement membrane assembly, stability and activities observed through a developmental lens. Matrix Biol., v. 22, n. 7, p. 521-38, 2004.

YURCHENCO, P. D.; O'REAR, J. J. Basement membrane assembly. Methods Enzymol., v. 245, p. 489-518, 1994.

YURCHENCO, P. D. et al. Laminin polymerization in vitro. Evidence for a two-step assembly with domain specificity. J. Biol. Chem., v. 260, n. 12, p. 7636-44, 1985. 
YURCHENCO, P. D.; WADSWORTH, W. G. Assembly and tissue functions of early embryonic laminins and netrins. Curr. Opin. Cell Biol., v. 16, n. 5, p. 572-9, 2004.

ZELLWEGER, T. et al. Tissue microarray analysis reveal prognostic significance of syndecan-1 expression in prostate cancer. Prostate, v. 55, n. 1, p. 20-9, 2003.

ZUO, J. et al. Neuronal matrix metalloproteinase-2 degrades and inactivates a neurite-inhibiting chondroitin sulfate proteoglycan. J. Neurosci., v. 18, n. 14, p. 5203-11, 1998. 